RADOSŁAW DĄBROWSKI

Adam Mickiewcz University, Poznań
Images

vol. XXIV/no. 33

Poznań 2018

ISSN 1731-450X

\title{
Krzysztof Kieślowski \\ and Ingmar Bergman - once again about a certain artistic relationship
}

\begin{abstract}
AвSTRACT. Radosław Dąbrowski, Krzysztof Kieślowski and Ingmar Bergman - once again about a certain artistic relationship. "Images" vol. XXIV, no. 33, Poznań 2018. Adam Mickiewicz University Press. Pp. 87-107. ISSN 1731-450X. DOI 10.14746/i.2018.33.08.
\end{abstract}

Krzysztof Kieślowski and Ingmar Bergman belonged to different generations of film authors, but there was a certain artistic kinship between them. They were both interested in issues related to human existence, but their films also seem similar in terms of their aesthetic dimensions, in particular, their cinematographic style. Both directors also created films deriving from their private experience, often creating characters on screen who seem to be in some respect their alter egos. This articles deals with various similarities between the cinema of Kieślowski and Bergman.

KEYWORDS: death, disease, documentary film, fiction film, Krzysztof Kieślowski, Ingmar Bergman, Polish cinema, Swedish cinema

In the early 1980s, Ingmar Bergman said goodbye to the world of cinema. Fanny and Alexander (Fanny och Alexander, 1982) was the culmination of a long career, after which the Swedish director focused exclusively on theatrical and occasionally television activities.[1] Nearly forty years have passed since this breakup. Bergman died more than a decade ago, but in the world of film-making he is still present. He remains a source of inspiration for other artists.[2] His philosophy and formal solutions have always been referenced by young, beginning artists whose tendency to model themselves on outstanding masters of cinema should be considered a completely natural phenomenon. The greatness of Bergman, however, lies in the fact that over the past several decades he has also been a source of inspiration for equally recognized directors of international renown. On the one hand, these filmmakers were able to develop their own, individual style of telling stories in the language of moving pictures and find a place in the history of art and culture. On the other hand, in statements they made both on and off the screen, including when they wrote about their own films, they did not conceal the considerable significance of Bergman's artistic output in their artistic life. The Polish director Krzysztof Kieślowski belongs to this group.

[1] T. Szczepański, Zwierciadło Bergmana, Gdańsk 1999, p. 391.

[2] J. Płażewski, Historia filmu, 1895-2005, Warszawa 2010, p. 338.
[3] M. Haltof, Kino polskie, trans. M. Przylipiak, Gdańsk 2004, p. 182.

[4] T. Szczepański, "Kieślowski wobec Bergmana, czyli Tam, gdzie spotykają się równoległe”, [in:] Kino 
Associations between this representative of the Cinema of Moral Anxiety (in using this term coined by Janusz Kijowski[3], I am bearing in mind Kieślowski's rather critical attitude to the idea of being identified with a specific trend), a trend in Polish cinema of the 1970s, and Bergman, who is almost a synonym for twentieth-century Swedish cinema, appear in the works of eminent film scholars (e.g. Tadeusz Szczepański - author of "Kieślowski Compared with Bergman, or Where the Parallels Meet" ["Kieślowski wobec Bergmana, czyli Tam, gdzie spotykają się równoległe"] [4]). Kieślowski himself wrote openly about his fascination with the cinema of the director from Uppsala:

There was no strict censorship at the School. They showed us different films that people normally did not watch. (...) I have a lot of movies in my memory because they were just beautiful. (...) And then I watched Bergman's film Sawdust and Tinsel. I once had beautiful memories of this movie - but on the screen I saw something that I did not care about at all, something that was quite alien to me. I could not understand what I had seen in him - except for three or four scenes. I did not experience the tension with which I used to watch him. But Bergman then made other beautiful films and they gave me this tension. Among other things, this is what the magic of the screen is about, that suddenly, as a viewer, you are in some tension. You are in the world that the film shows.[5]

Kieślowski met Bergman at the Film School, and he was one of those directors who, according to the Polish filmmaker, was able to achieve in cinema something that could be described as a miracle:

I explain to my younger colleagues with whom I have classes: when you light a lighter, it means that the lighter has sparked, and if the lighter won't spark, it is broken. It means nothing else and it will not mean anything else. If once in every ten thousand times it turns out that it means something more, then someone has achieved a miracle. This miracle was once achieved by Welles, and in recent years by only director in the world, in my opinion, Tarkovsky. This miracle has been achieved several times by Bergman, several times by Fellini. Several people have succeeded. Ken Loach was also successful in the film Kes.[6]

It can be concluded from the passage cited above concerning Kieślowski's cinematic assessments, that he valued Andrei Tarkowski as a director more than Bergman, that he placed Bergman on a level similar to Orson Welles or Federico Fellini, and that one movie by Ken Loach may have influenced him more than several by Bergman. It seems, however, that both in Kieślowski's films and as in his statements, the Swedish artist was still more important.

Let us begin our consideration of Kieślowski's exceptional attitude to Bergman's achievements with a look at an essay written by the Polish director, "The Silence of Bergman" ("Milczenie Bergmana"). This is one of several texts that comprise The Magic of Cinema (Magia

Krzysztofa Kieślowskiego, ed. T. Lubelski, Kraków 1997, pp. 163-171.
[5] K. Kieślowski, Autobiografia, ed. D. Stok, Kraków 2012, pp. 33-35.

[6] Ibidem, pp. 159-16o. 
kina), a volume edited by Janusz Wróblewski. The collection contains essays written by Polish directors about favourite and inspiring films made by other filmmakers.

In the preface to The Magic of Cinema, Wróblewski draws attention to the fact that in his commentary on the works of Bergman, Kieślowski revealed himself more than in his occasional interviews. Wróblewski even writes that Kieślowski discerned in The Silence (Tystnaden, 1963) the mirror image of his own soul.[7] The essay begins with the words:

Bergman's silence is as intense as the absence of Fellini, Buñuel and Tarkovsky, [...] I wonder what made Bergman's The Silence different thirty years ago from other films of that time and why so many people in so many countries of the world wanted to watch it. Tone.[8]

In the passage cited here, a difference in the use of the word "silence" is clearly visible. First, it appears as an expression of a state which the author of the essay compares with the state of absence associated with other outstanding filmmakers. Only later, together with the second use of the word, does Kieślowski refer directly to the work discussed in the text.

Therefore, it can be concluded that by using the term "silence", taken from the title, the Polish director refers to the silence that characterises Bergman's works when one considers them more generally. Of course, there are a lot of films in which the author of Autumn Sonata (Höstsonaten, 1978) placed a special emphasis on the word; throughout most of this film we listen to intense conversations, emotionally charged and perfectly reflecting the conflict between the characters. However, the Swede made a number of works characterised by an ascetic use of the word, such as Persona (1966), Hour of the Wolf (Vargtimmen, 1968), Cries and Whispers (Viskningar och rop, 1972) or Face to Face (Ansikte mot ansikte, 1976) .

Kieślowski introduces a certain play of words at the beginning of his text. He titles his essay with the term "silence", which brings to mind a particular film, but it is also a description of a state related to peace, calmness or restraint in speech, which is characteristic of the filmic world Bergman built over many years. In this respect, the reality he created seems to be close to the one we encounter while watching Kieślowski's films. Both artists were perfectly aware of the meaning of the word as a means of expression in film. The stronger it sounded, the more economically it was used. It is enough to compare the Bergman's screenplays with those written by Kieślowski with his co-screenwriter (starting from No End [Bez końca] in 1984) Krzysztof Piesiewicz.

Kieślowski analyses The Silence by describing the Bergman's film as a kind of compilation of unanswered questions and understatements that open the gates to viewers' various reflections:

[7] Magia kina, ed. J. Wróblewski, Warszawa 1995, p. 6.
[8] K. Kieślowski, "Milczenie Bermana”, [in:] Magia kina, op. cit., p. 53. 
We will never know why and where the sisters went on a journey. We will not know why they stayed in an unknown, foreign town where no one speaks German, English, French or Swedish, and people in the street do not speak a word to one another. We will not know what country it is and who it is waging war against. We will not know whether Ester will die in this town or if she will return home. We will not know the content of the letter from Ester to Johan. I think Bergman does not know either. The pleasure of watching this film is not about solving the puzzle, because there is no such solution. It is about looking for the solution.[9]

The observations and remarks noted above by Kieślowski bring to mind a number of motifs from his works. For example, the letter from The Silence, the content of which remains unknown due to the language barrier for both the characters and the viewers (although, according to Jerzy Płażewski, the word written by the woman means "the soul" [10]). It can be associated with a mysterious letter from the final scene of The Decalogue: Four (Dekalog, cztery, 1988), which is burned by Anka and Michał without their learning its content. We will not understand more than Ester and Johan. The truth contained in the letter from The Silence will remain a mystery for us as well as for Anka and Michał from The Decalogue: Four.

In the passage cited above, both the word "puzzle" and the phrase "looking for the solution" appear. Kieślowski pointed out that Bergman does not give ready answers. The intention of the Swedish author is to provoke thinking, to leave the viewer with their own conjectures. In the Polish director's cinema there are similar understatements. It is enough to recall one of the most characteristic and remembered figures of The Decalogue, played by Artur Barciś. The author of the film series does not give us an unambiguous answer to questions about what role this character plays, who he is, or where he comes from. This undefined "element" of the world depicted by Kieślowski remains inscrutable to us, just like the country that is visited by the three characters in Bergman's The Silence.

In the essay, Kieślowski refers to several takes in which the characters are looking through a window. The film itself begins with a scene in which Johan is watching through the window a solar circle that extends above the horizon. The pair of siblings in Fanny and Alexander is also looking through the window to the world, just like David - the unfulfilled writer and father from Through a Glass Darkly (Såsom and en spegel, 1961) or the pastor Tomas Ericsson from Winter Light (Nattvardsgästern, 1963), who is going through a crisis of faith.

The Decalogue: One (Dekalog, jeden, 1988) also begins with a boy looking out a window. Paweł is observing a pigeon on the windowsill with fascination, whereas in The Decalogue: Two (Dekalog, $d w a, 1988$ ), Dorota often stands by a window in the stairwell - painfully experiencing her husband's serious illness. On the other hand, in The Dec- 
alogue: Five (Dekalog, pięć, 1988) / A Short Film About Killing (Krótki film o zabijaniu, 1988) Piotr's lawyer is looking through a window pane at Jacek, who is being taken from the court to prison. The heroines of The Double Life of Veronique (La Double vie de Veronique, 1991) also experience close contact through a window several times. In one of the most important scenes for the story, Véronique and Weronika are looking at each other for a short while. One is inside a coach on the Old Market Square in Kraków, while the other one is standing at a distance. The vehicle's window symbolically separates them.

A figure at a window is a recurring motif in the works of both Kieślowski and Bergman, for whom presence by a window pane represents a moment of suspension, contemplation, calm or reflection. This is a time when the characters looks inside themselves, when their innermost thoughts, dreams and fantasies come to the fore; it can be said that the character is face-to-face with their inner reflection.

In an essay about Bergman's film The Silence, Kieślowski draws attention to the final shape of the film's narrative structure, from which anything unnecessary has been removed. The Polish director appreciates Bergman for his minimalism, for his full awareness of what is unnecessary and what needs to be shown. In Kieślowski's opinion, even if the Swedish artist had not planned everything during the shooting, during the editing stage he knew exactly where to cut, where to let a given scene last a while, in which moment to reveal the action performed by a character, and when not to show something but only to suggest its presence, to leave it "to speculation".

Kieślowski writes in his essay, referring to the world presented in Bergman's The Silence:

The Silence takes place in the overwhelming atmosphere of a scorching day and a hot night, where there is room for eroticism and desire, but there is no room for love, and a lack of pity, compassion, or even understanding is a completely natural state. In this dark, gloomy, profoundly sad movie an unjustified light of hope lingers all the time, except for the action and the words uttered.[11]

The key concept here seems to be an "unjustified light of hope" which for Kieślowski is a "bright trace in the dark film". It is this light which makes the characters, despite their being in an extremely difficult position, not take a passive attitude and try to deal with the crisis, to repair their own mistakes and reach an agreement. A small glimmer of hope in a sad, depressing reality. There is a place for something that becomes a catalyst for taking action. Hope (in the Cartesian meaning the tendency of the soul to awake the conviction that one will achieve what they want[12]) may result from the presence of another human being (e.g. a child, as in The Silence) or from an intuitive, subconscious faith in the power of love. Anna and Ester cannot come to an agree- 
ment; the conflicts between them often occur, but this does not mean that in the depths of their souls they do not feel sisterly affection. Their relationship constantly oscillates between love and hatred.

This is also the case with another Bergman film, Cries and Whispers, in which Agnes's debilitating disease becomes the reason for a meeting between all three sisters. [13] They are unable to arrive at an agreement, which does not mean that they are indifferent to each other. They engage in dialogue and gradually deepen their mutual relations. Again, somewhere deep down, an unspoken feeling of sisterly love comes alive, and in the face of a tragedy results in attempts to reach an (even if utopian) agreement. Another work by the Swedish director, Autumn Sonata, talks about the meaning of motherly love. The bitter conflict between the mother and the daughter does not make both women turn their backs on each other. Instead of expressing indifference or even definitively severing the relationship between them, they take action and try to engage in fruitful dialogue.

The above examples confirm Kieślowski's remark about "a bright trace in the dark film" which, as one can see, can also be found in other films by Bergman, not only in The Silence. Similar "bright traces" were placed by Kieślowski in the stories he told on the screen. The words of the lawyer from Three Colours: White (Trois couleurs: Blanc, 1994) seem prominent when, while trying to solve Karol's complicated legal situation, he states: "There is a light in the tunnel".

Bergman's above-mentioned works prove yet another issue common to the characters from the films by Kieślowski and Bergman: in a confrontation with a crisis situation, the characters do not resort to some form of evasion, but instead face the problem that fate has placed before them.

In the book from which Kieślowski's essay comes, there is a text by one of his students from the film school in Katowice (Faculty of Radio, Television and Film of the University of Silesia), and a director of feature films, Waldemar Krzystek, who wrote about the trauma experienced by the main heroine from Kieślowski's No End (Bez końca, 1984): "The wife in No End cannot recover and there are no other, more important or more 'relevant' matters for her. Her husband's death is her basic problem, a breach in the sense and need of life".[14] Krzystek's remark brings to mind the findings of Jacques Lacan about the tendency of man to make attempts to tame a trauma by naming it, describing it, and including it in a narrative. Man cannot avoid a confrontation with a trauma, for after some time it will return with redoubled strength. Therefore, one should try to deal with it immediately, to let it be present in our everyday life in order to find a remedy in this direct relationship.

Urszula from No End, despite the great pain she feels after losing her husband, does not want to start a new chapter in life. Her uninter-

[13] T. Szczepański, Zwierciadło Bergmana, op. cit., p. 330 .
[14] W. Krzystek, "Stracone złudzenia”, [in:] Magia kina, op. cit., p. 107. 
rupted love for Antek makes her not only want to keep remembering him, but she also begins to believe in his metaphysical closeness, in a relationship with the deceased which has taken on a new form. The widow begins to look at the reality that surrounds her in a special way, reading (what she thinks are) hidden signs from her dead husband. Kieślowski shows that it is impossible to completely cut off the ties that connect us with our loved ones who have died. Their death does not mean a final forgetfulness. It is also not possible to effectively work through the trauma after their death in isolation from them, although their absence seems certain and irrevocable.

Over time, the protagonist from Three Colours: Blue also realises this. Julie, unlike Urszula, tries to break free from her previous life, from everything that reminds her of the loved ones she has lost in a car accident. The efforts of Olivier, her late husband's assistant, who is trying to complete the composer's Concerto for Europe, make the woman think back to her beloved and, in a sense, allows her to once again establish a relationship with him in a spiritual, metaphysical, and perhaps more symbolic manner, through art. According to Tadeusz Lubelski, when the heroine opens herself to people and breaks the isolation, she opens herself to transcendence[15].

Similar characters and motifs to those mentioned above from Kieślowski's films, are also found in Ingmar Bergman's films. The motif of trauma appears in his films many times: for example, in The Passion of Anna (En Passion, 1969), in which the character of Anna Fromm and her story bring to mind the history of Julie and Urszula from the above-mentioned works by the Polish director. The protagonist from Bergman's film tries to break free from the past after a car accident which she has caused and in which her husband and son were killed. At the same time, her newly established relationship with the writer Andreas proves that she is unable to live fully, and forget the past completely. Even in such a briefly cited description of the main conflict in The Passion of Anna, it is easy to see plot similarities with Three Colours: Blue.

In Persona Alma, a nurse, is supposed to help dumb Elisabeth recover her physical and mental condition, but over time, the relationship between the women and their closeness become the first chance for the former to overcome repressed dramatic experiences from her past. Complex moral and psychological processes are born between the protagonists, as Kazimierz Młynarz correctly puts it in the introduction to The Screenplays (Scenariusze) by Bergman.[16] Alma delivers a monologue, sharing her difficult experiences with the more experienced woman, resembling a patient during a visit to a psychologist. The young nurse does not avoid uncomfortable topics, but rather, processes them like a trauma, so that inner healing can be achieved in her everyday life.

[15] T. Lubelski, Historia kina polskiego. Twórcy, filmy, konteksty, Chorzów 2008, p. 544.
[16] I. Bergman, Scenariusze, trans. Andrzej

Asłanowicz, et. al., Warszawa 1997, p. 16. 
All of these couples: wife-husband, parent-child, and sister-sister, prove that both Kieślowski and Bergman, along with their shared description of a sad reality, also talked about love: one of six primary passions. [17] This was also noticed by the Polish director, although he drew attention to differences in their on-screen statements on this subject. In response to Hanna Krall's statement: "Bergman has no small realities at all...", Kieślowski replied: "But there are great feelings. Great love, great hatred, great fear. There are no great feelings in my films. He loves her and she loves him, but she loves him not enough not to leave him.....[18]

The theme of love is clearly present in the early, documentary period of Kieślowski's work. While shooting First Love (Pierwsza miłość, 1974), he watched the everyday life of Jadzia and Romek - a couple waiting for the birth of their first child. The five-minute short feature film Tramway (Tramwaj, 1966) also tells about an emerging fascination between two young people, and the relationship between a husband and wife became the main topic in the short television film Pedestrian Subway (Przejście podziemne, 1973). Love becomes one of the central themes in the later feature films by the Polish director, including No End and Decalogue: Six / A Short Film About Love (Krótki film o miłości, 1988). "Love is the main theme of the triptych. According to Grażyna Stachówna, Three Colours are an extraordinary story about various forms of love, sensual and spiritual, experienced deeply and banally, in a tragic and melodramatic, solemn and trivial way by young, mature and old people"[19].

In many cases, love from Kieślowski's perspective is not only a positive feeling, or a kind of interpersonal relationship characterised by happiness. In his films, love is often associated with a sense of unfulfillment, nostalgia, or a passion which passes away, is challenged or destroyed. The relationship between Filip Mosz and Irka in Camera Buff (Amator, 1979) descends into a serious crisis along with the development of the film interests of the man, with his devotion to his hobby at the expense of his family life. In the finale of The Decalogue: Six Tomek announces to Magda that the woman is no longer the centre of his interest. In The Decalogue: Three (Dekalog, trzy, 1988) Janusz leaves his own family on Christmas Eve to help his former lover, Ewa. In The Decalogue: Nine (Dekalog, dziewięć 1988), Roman begins to suspect his wife of infidelity, and Julie in Three Colours: Blue wants to destroy her feelings for her tragically deceased husband and start a new life "from scratch". Karol from White, on the other hand, experiences the drama of divorce and parting with a woman he still loves.

Thus, in Kieślowski's films, love is put to the test. The author of The Double Life of Veronique places his characters in situations in which

[17] R. Descartes, op. cit., pp. 75-76.

[18] K. Kieślowski (in a conversation with Hanna Krall), “Zrobiłem i mam” [in:] Kino Krzysztofa Kieślowskiego, op. cit., p. 275.
[19] G. Stachówna, “Trzy kolory - wariacje na jeden temat”, [in:] Kino Krzysztofa Kieślowskiego, op. cit., p. 93. 
their feelings for another person are subject to verification. Viewers follow the characters' lives to find out if the relationship survives. It is similar with Bergman. On the one hand, the theme of love is an inseparable element of the world created by him; on the other, it is difficult to find a purely romantic incarnation of it.

Bergman first talked about love in his second film It Rains on Our Love (Det regnar på vår kärlek, 1946). It is a relatively successful stylisation of a classic 1940 s Hollywood melodrama. Three years later, he made Thirst (Törst, 1949), a story in which a married couple comes to painful conclusions about their own relationship. The journey they take is a symbolic means of covering the distance to the end of a love relationship. In one of Bergman's most underrated films, Brink of Life (Nära livet, 1958), the author showed two sides of waiting for the birth of a child. For one couple it is a reason for positive excitement; for the other, the coming birth is connected with a vision of imminent trouble.[20] In the masterpiece Through a Glass Darkly, the marital relationship between Karin and Martin is disturbed because the man, who is a doctor, cannot adequately relate to the ill woman. Unfulfilled love is shown in Winter Light. In Fanny and Alexander, the beginning of life with a Protestant pastor means for Emilie and her children unconscious surrender to terror and becoming a victim of domestic violence. The power of love was put to the test by Bergman also in the films Shame (Skammen, 1968) and Hour of the Wolf. In the former, a couple gets to know each other anew in the face of war, while in the latter a crisis is determined by the psychological problems of one of the spouses, this time the man (as in Through a Glass Darkly).

Kieślowski and Bergman were willing to talk about love on screen, and they asked questions about its permanence and authenticity. They did not avoid discussing the pessimistic overtones of their stories.

Another common point for the works by Kieślowski and Bergman is the subject of death. In his essay, the Polish director writes that death is the subject of cinema because it is the subject of life.[21] In his films, it is not just an event, a reason for the viewer to sympathise with the character who experiences the loss of the loved one. Death is incorporated into a complex network of semantic dependencies in such films as No End, The Decalogue: One, The Decalogue: Five, The Double Life of Veronique or Three Colours: Blue.

At this point it is worth turning attention to the location of the subject of death in Kieślowski's films in the context of the struggle for life while battling against a dangerous and sometimes deadly disease, as shown in the documentary film Hospital (Szpital, 1976) or in a much more meaningful way in the TV drama The Decalogue: Two.

The theme of the struggle of a man with a devastating illness or an impending death is also present in Bergman's films. Let us menp. 228. 
tion here Cries and Whispers and Fanny and Alexander. In the works of both Kieślowski and Bergman, we also find the motif of death by suicide: in the former in No End, and in the latter in Winter Light and The Serpent's Egg (Ormens ägg / Das schlangenei, 1977). We also watch scenes of characters trying to take their own lives in Three Colours: Blue and in another version (a commissioned murder) in Kieślowski's Three Colours: White and in Bergman's Face to Face. In the works of both artists, there are also examples of death resulting from murder. For Kieślowski, this applies to two versions of one film (The Decalogue: Five/A Short Film About Killing), and for Bergman to such films as The Virgin Spring (Jungfrukällan, 1960), The Seventh Seal (Det sjunde inseglet, 1957), and A Ship Bound for India (Skepp till Indialand, 1947), where an attempt to commit a crime is depicted.

Here, it is worth returning to the mysterious character from The Decalogue, played by Artur Barciś, whom Slavoj Žižek calls an angel.[22] The Orthodox theologian Michał Klinger goes even further in his interpretation by describing the character as the "angel of death".[23] He stated that the mysterious hero appears when the threat of death becomes noticeable, and in some cases even announces it. The angel from The Decalogue can therefore be a warning or a harbinger of impending death which will result from something unexpected, some sudden tragedy. Klinger writes that the "angel of death" appears when the risk of death increases.

It is no different with the famous The Seventh Seal by Bergman. The Swedish director personified Death in his work, giving it features that are slightly different from its traditional scary image of a skeleton, as in the medieval dance macabre. Bergman was more concerned with giving death a real shape and with certain natural associations connected with its pictorial and literary images, such as predominantly black attire. Death in The Seventh Seal might be considered a villain. On the other hand, this character simply fulfils his assigned role, and at the right moment comes for Antonius Block, just when it is time for him to leave the world. The character of the angel of death from The Decalogue: One and death from The Seventh Seal play similar, but not identical roles. They accompany a man at the moment of the transition from the reality of the earth to that beyond, with the border getting closer and closer until it is finally crossed.

Here, it is worthwhile asking about the sources of interest in the topic of death in both Kieślowski and Bergman. The latter explained the creation of the character of Death in The Seventh Seal with the fear of death that had accompanied him since childhood, becoming especially strong in adolescence. He thought about it constantly, and he was afraid of the day he would die and of what was going to happen to him.[24]

[22] S. Žižek, Lacrimae rerum. Kieślowski, Hitchcock, Tarkowski, Lynch, trans. G. Jankowicz, et. al., Warszawa 2011, p. 70.

[23] M. Klinger, “Strażnik wrót. Rzecz o Dekalogu
Krzysztofa Kieślowskiego", [in:] Kino Krzysztofa Kieślowskiego, op. cit. p. 56.

[24] I. Bergman, Obrazy, trans. T. Szczepański, Warszawa 1993, pp. 236-238. 
Therefore, by placing death in the film, he wanted to undergo a certain therapy, to attempt to overcome this fear of the final end of life, to get rid of it like an onerous burden in his existence.

Perhaps the source of the theme of death in Kieślowski's films should also be looked for in the personal experiences of the Polish artist. In the documentary Krzysztof Kieślowski: I'm So-So... (1995) by Krzysztof Wierzbicki, the film's hero openly talks about the pain caused by his father's early death from tuberculosis. Even before the majority of the works mentioned above were made, Kieślowski had already lost his mother, with whom he was connected by a strong bond. What is more, the Polish director wrote in his autobiography about the absence of his parents, which was an acute problem for him. [25]

Both Kieślowski and Bergman created cinema in which the presence of the creators is strongly felt, both in terms of references to their own biography and authorial cinematic style. The director François Truffaut believed that: "A film should express the one who has made it".[26] However, the French director was not referring to looking at a film work from the angle of its director's biography, but to a style that reveals the personality of the filmmaker. In the case of Kieślowski and Bergman, one can also talk about the autobiographical themes contained in their works. These sometimes take the form of allusions or deeply hidden references to personal experiences.

Filip Mosz from Camera Buff can be treated as an alter ego of Kieślowski himself - a director who for many years struggled in his artistic activity with moral dilemmas similar to those of the protagonists of his films, like the amateur filmmaker played by Jerzy Stuhr. Before Kieślowski was accepted into the directing program at the Łódź Film School, he got to know the theatre backstage as a technical employee at a Warsaw theatre (Teatr Współczesny). As Tadeusz Lubelski remarks, the character of Romek from Personnel (Personel, 1975) can be treated as an alter ego of the young Kieślowski.[27] Lubelski uses a similar key to interpret the character of the Judge from Three Colours: Red, who in his opinion appears in this film as a hidden director of events[28], i.e. someone very similar to Kieślowski, who as an artist directs the fate of the characters he has created. It is not difficult to guess that many autobiographical experiences were also included in his earlier film story about Witek Długosz - Blind Chance (Przypadek, 1981).

Ingmar Bergman's eventful life was also material for a literary work or a screenplay. His private life seems all the more important in the context of his artistic achievements given that a significant part of the Swedish filmmaker's work is consciously autobiographical in nature. And to a greater extent, it seems, than in the case of Kieślowski's films.

[25] K. Kieślowski, Autobiografia, op. cit., p. 21. [26] A. Helman, et. al., Historia myśli filmowej: podręcznik, Gdańsk 2007, p. 184.
[27] T. Lubelski, op. cit., p. 309.

[28] Ibidem, p. 544. 
In the documentary Bergman - A Year in a Life (Bergman - ett år, ett liv, 2018) by Jane Magnusson, it is said that in the mid-1950s Bergman decided that if he was to shoot great films, he had to start talking about himself. The year 1957 was a breakthrough in this respect, when in writing subsequent screenplays, the Swedish creator began thinking primarily about his own life experiences.

He drew upon the experiences of his early youth - and on the screen showed the world he saw through the eyes of a child (The Silence, Fanny and Alexander) - and also upon later stages of his life, when the everyday dilemmas he faced were related to a crisis of creation (Hour of the Wolf) or a feeling of loneliness in emigration (The Serpent's Egg). Some of these problems, such as a difficult relationship with one's mother (Autumn Sonata) or an equally complicated marital relationship (Brink of Life), or depressive states that lead to a nervous breakdown (Face to Face) were presented by locating female characters at the centre of his films. As a result, he managed to combine the autobiographical character of his works with evidence of a special understanding of a woman's nature, which he demonstrated as a cinema artist.

Both artists being compared here seem to be linked by one more thing: seeking God, an attempt at reaching him. This can be clearly seen in their films although they distanced themselves from characterising their works as religious. Kieślowski himself opposed the wording "being religious" and did not want to be attributed to the institution of the Catholic Church.[29] In turn, Bergman, in the introduction to his Screenplays, wrote: "I do not worship any god. I have my angels and my demons".[30] However, in their works, both creators addressed fundamental questions about the existence of God and his role in the world in which the characters of their films live.

In Kieślowski's career, the period connected with making The Decalogue (ranked by Bergman among the five contemporary films which "brought the greatest benefit" to him[31]) should be recognised as the most "religious", although the director himself questioned the reading of the drama in a religious context:

But here there are no references to the Bible. You cannot even see any priest. (...) I did not want to treat the Ten Commandments too literally and I hope that I succeeded. (...) In our time, the God of the Old Testament, cruel and punishing, has been replaced by the God of the New Testament, a bearded sage who forgives everything. In the human interior, the need for both these images of God has been preserved. But I do not insist on any categorical judgment. I make all my films from the point of view of someone who does not know and who tries to understand.[32]

According to Tadeusz Lubelski, The Decalogue is supposed to make the viewer more interested in religious reflection rather than be

[29] J. Wróblewski, Reżyserzy, Warszawa 2013, p. 425.

[30] I. Bergman, Scenariusze, op. cit., p. 5.

[31] M. Haltof, op. cit., p. 247.
[32] K. Kieślowski (in a conversation with Vincent Ostria), Przypadek i konieczność, [in:] Kino Krzysztofa Kieślowskiego, op. cit. pp. 283-284. 
an explicitly religious work.[33] Kieślowski, as Jerzy Płażewski remarks, did not take the role of a preacher who proclaimed the truth of faith but demonstrated the potential attitudes of a modern man in relation to the Decalogue's commands.[34] It is not that the Polish director completely refuses to consider the series of ten films as a collection of works marked by religious themes: "We left religious categories to the side. But I hope that in these films something of these values will be found. Metaphysics for sure....'[35]

Kieślowski, the author of The Decalogue, seems to be playing a game with the viewer. According to Slavoj Žižek, in this film cycle, the Commandments have been relocated, "the course has been changed", so that, for example, The Decalogue: One refers to the Second Commandment, and finally The Decalogue: Nine (1988) leads us back to the First.[36] The Slovenian researcher is mainly right, but why should one limit one's thinking about individual episodes of the series as referring only to one Commandment? The subsequent episodes have not been titled: "Commandment I", "Commandment II" etc., but each of the titles refers to the Decalogue - a set of basic moral precepts. It can be deduced from this that each episode of the series is connected, at least potentially, with at least a few of the Ten Commandments - and not just one.

The religiousness of The Decalogue is ambiguous, hidden between the lines. We see a similar phenomenon in Bergman's works. In addition to films directly related to the issues of faith, we can find here films that reveal the religious theme hidden in them only with a more in-depth analysis. This is the case with such films as Through a Glass Darkly or The Silence.

Tadeusz Szczepański writes about the religious dimension of the works by Kieślowski and Bergman:

The idea of God straight from the Old Testament tradition is common to both artists, but here their images differ too: in Bergman's films, God transforms into an ominous spider that threatens the destruction of the human personality (Through a Glass Darkly), for Kieślowski he is a silent witness to our sinful choices (The Decalogue).[37]

I do not fully share the above judgment. Of course, in Kieślowski's films, God does not appear in the form of a spider, but if we think about him in the context of the destruction of human personality indicated by Szczepański, is a similar role not played by the computer-god of The Decalogue: One? Paweł's father, in a sense, deified the technique and science represented in the film by the aforementioned electronic brain. His faith in its infallibility led him to a great personal tragedy and to the edge of despair.

[33] T. Lubelski, op. cit., p. 457.

[34] J. Płażewski, op. cit., p. 493.

[35] K. Kieślowski (in a conversation with Vincent

Ostria), Przypadek i konieczność, op. cit., p. 276.
[36] S. Žižek, op. cit., pp. 58-59.

[37] T. Szczepański, Kieślowski wobec Bergmana, czyli Tam, gdzie spotykaja się równoległe, op. cit. p. 170. 
In Through a Glass Darkly, standing in a mysterious room on the first floor, Karin awaits the coming of God, who finally appears to her in the form of a monstrous spider, personifying fears born out of a combination of religious obsession and unsatisfied sexual desire.[38] Karin feels betrayed and disappointed. After all, she did not ultimately experience the revelation she had expected. Can we interpret what happens to her in terms of punishment for the sin of incest? And is a similar question about divine punishment not present in the background of the story of the father scientist and his son who dies under the ice as a result of playing on a frozen pond in the neighbourhood? Bergman and Kieślowski are far from answering such questions, the presence of which, however, echoes in the films made by them.

Through a Glass Darkly belongs to the stage in Bergman's work in which the silence of God is an important motif. This is another example of the similarity between the Swedish and the Polish directors. Tadeusz Szczepański notes that in The Decalogue God does not answer and remains a passive observer of human errors, as in many of Bergman's films. In his films the characters are led to doubt God's existence, as in one of the plots from Prison (Fängelse, 1949), a film Bergman made at the beginning of his career, and in the later Seventh Seal, as well as in such films as Winter Light, The Silence, Shame, Cries and Whispers, or Fanny and Alexander.

Let us mention here another significant remark made by $\mathrm{Ta}$ deusz Szczepański which refers to the subject of art itself and the role that both filmmakers attribute to it in their works. What does art give to man? - Bergman and Kieślowski seem to be asking in their works. And they answer: it can bring salvation (Summer Interlude [Sommarlek, 1951] and Three Colours: Blue), suffering (The Magician [Ansiktet, 1958], Persona, or Hour of the Wolf), or even death (The Double Life of Veronique).[39] It is not without reason that musicians (Music in Darkness [Musik i mörker, 1948], Shame, Autumn Sonata, and Three Colours: Blue or White), writers (Through a Glass Darkly), singers (The Double Life of Veronique), theatre actors (The Magician, Persona, and Personnel), film directors (Camera Buff), painters (Hour of the Wolf), circus artists (Sawdust and Tinsel [Gycklarnas afton, 1953], The Serpent's Egg), and dancers (Summer Interlude) often appear among the characters in films by Bergman and Kieślowski. Both directors not only dealt with art but also skilfully talked about it, seeking answers to the question of their own role in the world.

Apart from artists, children play an equally important role in many of the films by the two directors. Showing the world through the eyes of a child is only seemingly a simple task. Kieślowski and Bergman used as their protagonists young people just getting to know the world. The main hero of The Decalogue: One is seven-year-old Paweł. In the

[38] I. Bergman, Laterna magica, trans. Z. Łanowski, Warszawa 1991, p. 65.
[39] T. Szczepański, Kieślowski wobec Bergmana, czyli Tam, gdzie spotykaja się równoległe, op. cit. p. 169. 
TV report The Photograph (Zdjecie, 1968), what determines the actions of Kieślowski-documentarian is a photograph depicting two Warsaw boys at the end of the war. In fact, they are the most important figures in this half-hour documentary; they are its heroes. The director of the documentary is following in their footsteps, he wants to find out what their post-war fates were. The personified Youth is represented in a special way in Kieślowski's works by such figures as Tomek in The Decalogue: Six / A Short Film About Love, a slightly older protagonist in The Double Life of Veronique, or the young Valentine from Three Colours: Red, who, in being set against the retired judge, seems almost like a child. And finally, one other film begins with an overwhelming child's cry: The Decalogue: Seven (Dekalog, siedem, 1988). Here, the child is also the key character for the development of the film's action.

Reality is shown through the eyes of a child, or a person entering adulthood, in several Bergman films. Let us mention It Rains on Our Love, Summer with Monika (Sommaren med Monika, 1953), Brink of Life, The Silence (especially in this work one can indicate many takes photographed from such a camera setting that matches the perspective of a child[40]), or Fanny and Alexander. There are characters in the foreground who are still shaping their thinking about the world around them.

Kieślowski and Bergman are also linked by the ability to create unique stories about women on the screen, to present female characters with a complex personality and psychology. The Polish director referred to this issue in a commentary on The Double Life of Veronique:

Of course, Veronique is a classic movie about a woman, because women feel more strongly, they sense more, they have more sensitivity, more intuition and pay more attention to it. One cannot make such a movie about a man. (...) I was once criticised in Poland that I made flat characters of women, without three-dimensions and without an understanding of the essence of femininity. (...) Perhaps this was the reason why I thought I would make a movie about a woman from the point of view of a woman.[41]

Kieślowski portrayed women in two very important documentary films, First Love and Seven Women of Different Ages (Siedem kobiet $w$ różnym wieku, 1978). However, against the background of his documentary oeuvre, these films, if viewed through the prism of women's themes, constitute an exception. In the first feature films by Kieślowski, female characters appear only in the background, giving way to male protagonists. They are often just their wives, like the life partner of Stefan Bednarz in The Scar (Blizna, 1976) or Antoni Gralak in The Calm (Spokój, 1976). Irka from Camera Buff is a similar character although in contrast to earlier films, this character is more complex, and in the course of the story undergoes a significant transformation - from a sensitive and reliable wife into a woman full of internal heat and energy, 
who is ready to leave Philip when his film passion begins to destroy the balance between private and professional life in the Mosz family. In principle, the role of women does not change in Kieślowski's next film. The characters depicted in it, though remarkable and suggestively outlined and played, are still more of a background than the centre of the story of three variants of Witek Długosz's fate in Blind Chance. The fundamental change in "women's issues" in Kieślowski's films is brought by No End.

On the one hand, this is a story in which a woman's actions are still determined by a man (Tadeusz Lubelski points to a paradox - the deceased Antek, who, despite the lack of retrospective scenes, is the most important character in the film[42]), on the other hand, Kieślowski portrayed a female character here as he had never done before in his career, making her the protagonist. The same will happen in The Double Life of Veronique and Three Colours. Some parts of The Decalogue are also interesting in this respect, including parts one, three, four, six and nine, and in particular, parts seven and eight, in which women characters come to the fore. In some episodes in the series, the women characters become characteristic femmes fatales who are unfaithful to their partners, like Hania in The Decalogue: Nine, or humiliate their admirers, like Magda in The Decalogue: Six / A Short Film About Love; or provoke incestuous intercourse, like Anka from The Decalogue: Four; or trick a man into leaving his house and his family on Christmas Eve, like Ewa in The Decalogue: Three.

In The Double Life of Veronique and Three Colours, a shift in emphasis from male to female characters was made in an even clearer way. In physical terms, the actresses change over time, often having a more attractive appearance or more subtle facial features (Juliette Binoche, Irène Jacob) than in earlier films. Their beauty is brought out, or even literally illuminated, by the cameramen cooperating with Kieślowski. In this respect, The Double Life of Veronique and Three Colours are two films that bring Kieślowski closer to Bergman, both in terms of the selection of actresses and the role that the director entrusted to the operators in creating the work.

From the beginning of his career Bergman wrote screenplays in which female characters played key roles. However, one can also point out some exceptions, films in which men appear in the foreground, like Wild Strawberries (Smultronstället, 1957) or The Magician. However, in many cases these are characters who are mentally weak (Sawdust and Tinsel, Through a Glass Darkly, Winter Light, Hour of the Wolf, Shame), or whose existence without the participation of women would be incomplete. There are plenty of examples among Bergman's films in which the title itself indicates the key role of women in the film's story (Secrets of Women [Kvinnors väntan, 1952], Summer with Monika, Dreams [Kvinnodröm, 1955], All These Women [För att intent alla dessa

[42] T. Lubelski, op. cit., p. 455. 
kvinnor, 1964], the documentary Karin's Face [Karins ansikte, 1984], and in part, Fanny and Alexander), which in itself proves the rank of female characters in these films.

A visual sign of the exceptional role played by women in Bergman's and Kieślowski's films are the takes of women's faces in their films. One can even talk about an enchantment with a woman's face as another common feature of the two directors.

Mikołaj Jazdon aptly notes that in Kieślowski's documentary films a fascination with filming the human face is constantly noticeable, from the first to the last work. The Office (Urzad, 1966), I Was a Soldier (Bytem żolnierzem, 1970), Factory (Fabryka, 1970), Refrain (Refren, 1972), X-Ray (Prześwietlenie, 1974), Curriculum Vitae (Życiorys, 1975), I Don't Know (Nie wiem, 1977), Seven Women of Different Ages, and Talking Heads (Gadajace głowy, 1980) consist almost exclusively of close-ups[43] showing the characters' faces, as if Kieślowski was trying to keep his characters so close so that the viewer could sink more deeply into their world and thus better understand it.

Comparing Bergman's work with the films Kieślowski made in the late 1980 s, one can point to yet another common feature linking the achievements of both filmmakers. This is the apolitical nature of their films. While in the case of Bergman this is a constant and unchangeable feature of his work, in the case of Kieślowski, one can talk about a departure from politics, which had been an important aspect of his documentary and feature works before The Decalogue. Tadeusz Lubelski described the feature debut of the Polish director, which was the medium-length TV film Personnel, as a political parable.[44] Some years later, Kieślowski clearly distanced himself from attributing political connotations to his works: "The subject of my films has never been politics but a description of the world". [45] In fact, in his foreign works there are no politics at all. Although in The Double Life of Veronique a scene of a political demonstration and riots on the Old Market Square in Kraków in the early 1990s appears, it is in fact merely a faintly outlined background for the main plot in the film, which is the story of the protagonist.[46] Politics is also virtually absent earlier in The Decalogue, which from the very beginning was for Kieślowski and his co-writer Krzysztof Piesiewicz one of the basic artistic assumptions adopted when writing the screenplay and later when filming this series:

We ruled out all the politics. (...) We decided to exclude politics because we wanted to eliminate something that is commonly referred to as PRL (communist-era Poland). (...) We believed that in the world, also around us, there are problems more important than politics: everything we really live and breathe. What we live, not what we talk about. And finally the last reason for abandoning politics: because for some time now I haven't been able to stand politics. It annoys me as a thought, as a way of life, of

[43] M. Jazdon, Dokumenty Kieślowskiego, Poznań 2002, p. 117.

[44] T. Lubelski, op. cit., p. 307.
[45] J. Wróblewski, op. cit., p. 421. [46] M. Haltof, op. cit., p. 248. 
spending energy. And especially politicians irritate me, those who know exactly how to arrange everything.[47]

Marek Haltof states that Kieślowski, unlike Andrzej Wajda or Krzysztof Zanussi, was never directly involved in politics, nor was he "political" in his films or public appearances.[48] Even if people connected with the communist party circle or some political events appeared at the centre of the story, social, ethical, and moral dilemmas were very often the most important.

Bergman rarely talked about politics. In the introduction to the collection of his screenplays he confesses: "Unfortunately, I would like to join the party of the timid, but as far as I know, such a party does not exist".[49] In addition, the artist in the vast majority of the screenplays he wrote did not specify precisely the time or place of the on-screen events. The Swedish and Polish directors were both primarily interested in characters outside politics, and focused on dimensions of existence through which their films gained the character of universal stories. It is not without reason that the films made by both directors have attained international fame and are understood all over the world. Today, as well, viewers of Kieślowski's and Bergman's films do not have to watch them equipped with knowledge about the political realities of the times in which they were made in order to find in them attempts to reflect the reality of communist-era Poland or Sweden in the second half of the $20^{\text {th }}$ century.

Another noteworthy place which links the work and biography of both directors discussed here is that directly related to the way in which they both parted with the cinema. After completing Three Colours, Kieślowski upheld his earlier declaration about ending his film directing career. In interviews, he admitted that he was ready to write screenplays, and did not rule out writing subsequent stories along with Krzysztof Piesiewicz. Ingmar Bergman, after making Fanny and Alexander left the world of cinema and devoted himself to work in theatre and television.

Incidentally, the creation of television works is also a joint experience for both directors. Kieślowski made documentaries (The Photograph, First Love, Curriculum Vitae) and feature films for television (Personnel, The Calm, and the series The Decalogue), and produced adaptations of plays for TV theatre (Checking the King [Szach Królowi, 1972], Licence for Culling [Pozwolenie na odstrzat, 1972], Two for the Seesaw [Dwoje na huśtawce, 1976], The Card Index [Kartoteka, 1979]). In Bergman's oeuvre one can find a number of a works made for television, including The Rite (Riten, 1969), From the Life of the Marionettes (Aus dem Leben der Marionetten, 1980), After the Rehearsal (Efter repetitionen, 1984), Fårö Document (Fårödokument, 1970), Fårö Document

[47] K. Kieślowski (in conversation with Bożena Janicka), "Beze mnie" [in:] Kino Krzysztofa Kieślowskiego, op. cit., pp. $277-278$.
[48] M. Haltof, op. cit., p. 244.

[49] I. Bergman, Scenariusze, op. cit., p. 5. 
1979 (Fårödokument 1979, 1979), the series Scenes from a Marriage (Scener ur ett åktenskap, 1973), and his last work, filmed four years before his death, Saraband (2003).

Finally, I would like to draw the attention to a film that testifies to Kieślowski's special interest in Bergman. It is a documentary directed by Erik Lint Krzysztof Kieslowski: A Masterclass for Young Directors (1995).[50] An important part of it is a recording of workshops that the Polish director conducted in 1994 with two adepts of this art: Leif Magnusson and Francesco Ranieri Marinotti. The original assumption for this task consisted in choosing a script from a previously shot film that was a successful artistic work, and attempting to recreate scenes selected from it. Kieślowski decided to take Bergman's Scenes from a Marriage. The choice he made could be seen as another expression of his appreciation for Bergman. Kieślowski justified his decision in this way:

I can identify with what Bergman says about life, about what he says about love. I identify more or less with his attitude towards the world (...) towards men and women and what we do in everyday life (...) forgetting about what is most important.[51]

In Scenes from a Marriage, Johan and Marianne experience many difficult moments: separation, a repeated drifting apart and attempts at getting closer, extramarital affairs. Their divorce should mark the end of their relationship. Paradoxically, however, numerous perturbations lead them to become convinced that despite their many differences, the feelings between them have not been lost. Common sense tells them not to be with each other anymore, but deep down they still love each other. The most important part of the documentary shows the making of the scene in which Johan informs Marienne about his leaving her after becoming involved with another woman. This is the climax of the series, which (like many Bergman films) has a very theatrical character. Bergman not only skilfully combined the profession of filmmaker with theatrical and literary work, [52] he was also able to give films the dimension and power of stage drama, somehow melting stage and screen art into one.

The theatre was also close to Kieślowski, although he directed only one play based on his documentary Curriculum Vitae. However, like Bergman, during his early youth he was passionate about the theatre, and he entered film school with the intention of graduating in theatrical direction.

The workshops shown in the aforementioned documentary film were conducted with six actors (the team included Reinout Bussemaker, Pamela Knaack, Shaun Lawton, Matthias Maat, Dulcie Smart and

[50] A Masterclass for Young Directors [film], [online], dir. Erik Lint, available online: https://www.youtube. com/watch?v=u-Iy3JyPAog (accessed: September 6, 2018).
[51] J.G. Kickasola, The Films of Krzysztof Kieslowski: The Liminal Image, New York 2006, p. 27.

[52] J. Płażewski, op. cit., p. 238. 
Nelleke Zitman), who were divided into three pairs. New faces helped to see the story from Scenes from a Marriage without the context of Bergman's work. At the same time, however, when the names of the main characters, Johan or Marianne, are heard from the screen, the viewer's memory of the Bergman series immediately evokes the characters played by the duet Liv Ullmann and Erland Josephson. Kieślowski's classes in staging Bergman's text also confirm that the words of the script are only a starting point for a stage or film realisation. The actors directed by the director give them their final expression. In the aforementioned documentary we watch different variants of the scene. In the first variant of the conversation between the couple does, the actor playing Johan exclaims: "Say something!". In the next two variants of this scene (with changes in the actors performing the role) the sentence is spoken much more calmly. Differences are also noticeable in how the actresses play their roles, which is what Kieślowski states in the film. Pamela Knaack showed Marianne as a fragile, sensitive woman, for whom the world came to an end when Johan announced that he loved another woman. Nelleke Zitman, playing the same role, reacted to her husband's words in the opposite way - she showed her strength as if she felt hatred for her husband, which gave her the strength to fight. The scenes directed by Magnusson are marked with strong emotions. They contrast with those realised by Marinotti, in which there is a lot of peace and restraint.

There are plenty of examples in the world of cinema where we see a clear relationship between the films of different directors. Sometimes it results from an explicit inspiration of the work of the other. Conducting an "authorial policy" directed by a similar vision of cinema, connecting a group of artists, sometimes occurs within one generation of directors. In the history of cinema, this has often led to the crystallisation of a particular artistic trend within a cinematic tradition. But artistic links between different artists can have many different causes. They may even arise from the need to pay tribute to a valued master and their art, by peculiarly continuing the direction of the artistic search they have chosen, in order to make their own mark by creating their own works, not epigones.

Kieślowski and Bergman asked important questions in their films about the condition of modern man, about the rightness of moral and ethical choices. They confronted their characters with problems and situations strongly affecting their existential condition. The problems of illness, depression and death were noteworthy in their work. However, they did not perceive man as a lonely individual, but living in relation to others. Hence the presence in their films of topics related to the family, love or friendship.

Perhaps by comparing the achievements of other filmmakers, we will find what unites them, what makes their achievements related. One should not, therefore, perceive the relationship between Kieślowski and Bergman as something absolutely unique. However, in the case of these 
great cinema artists, the relationship that connects their achievements seems to go beyond what is easy to grasp, regarding the subject matter of their films or formal solutions used by them, and which is related to the exceptional sensitivity of both artists to the surrounding reality, leading them to define their creativity in terms of a certain mission to discover and express the truth about the world, with the hope that the questions posed by them will encourage viewers themselves to attempt to answer them, or at least to talk together about them. The continued interest in Bergman's and Kieślowski's cinema seems to confirm that their artistic mission was successful.

Bergman I., Laterna magica, trans. Z. Łanowski, Warszawa 1991

Bergman I., Obrazy, trans. T. Szczepański, Warszawa 1993

Bergman I., Scenariusze, trans. A. Asłanowicz, et. al., Warszawa 1997

Derrida J., Of Grammatology, trans. G. Chakravorty Spivak, Londyn 1998

Descartes R., Namiętności duszy, trans. L. Chmaj, Warszawa 1958

Haltof M., Kino polskie, trans. M. Przylipiak, Gdańsk 2004

Helman A., et. al., Historia myśli filmowej: podręcznik, Gdańsk 2007

Hendrykowski M., Historia filmowego Oscara, Warszawa 1988

Historia polskiego filmu dokumentalnego (1945-2014), ed. M. Hendrykowska, Poznań 2015

Jackiewicz A., Kino polskie, Warszawa 1983

Jazdon M., Dokumenty Kieślowskiego, Poznań 2002

Kickasola J.G., The Films of Krzysztof Kieslowski: The Liminal Image, New York 2006

Kieślowski K., Autobiografia, ed. D. Stok, Kraków 2012

Kino Krzysztofa Kieślowskiego, ed. T. Lubelski, Kraków 1997

Lenczewski R., Okiem operatora, Łódź 2014

Lubelski T., Historia kina polskiego. Twórcy, filmy, konteksty, Chorzów 2008

Magia kina, ed. J. Wróblewski, Warszawa 1995

Osęka A., Mitologie artysty, Warszawa 1970

Płażewski J., Historia filmu, 1895-2005, Warszawa 2010

Szczepański T., Zwierciadło Bergmana, Gdańsk 1999

Ullmann L., Przemiany, trans. A. Kreczmar, Warszawa 1988

Wróblewski J., Reżyserzy, Warszawa 2013

Žižek S., Lacrimae rerum. Kieślowski, Hitchcock, Tarkowski, Lynch, trans. G. Jankowicz, et. al., Warszawa 2011. 